\title{
Inequality in Brazil: The Contribution of Pensions*
}

\author{
Rodolfo Hoffmann ${ }^{* *}$
}

Summary: 1. Introduction; 2. The data; 3. Decomposition of the Gini index; 4. Distribution in 10 income classes; 5. Results of the decomposition of the Gini index; 6 . Conclusions.

Keywords: inequality; Brazil; pensions; Gini index.

JEL codes: D31; D63.

This paper analyzes the contribution of components of per capita household income to total inequality of the income distribution in Brazil and its regions, using the corresponding decomposition of the Gini index. The income components considered are: income from the main job (activity), income from other jobs, pensions, donations, rent, interest, and other incomes. Only income from the main job and donations have a concentration ratio that is lower than the overall Gini index. One of the main results is that income from pensions contributes to increase overall inequality in Brazil, particularly in the metropolitan regions. Given the aging of the population, without change in the pension rules, the contribution of pensions in increasing inequality will be even stronger in the future.

Este artigo analisa a contribuição de parcelas do rendimento domiciliar per capita para a desigualdade da distribuição da renda no Brasil e nas suas regiões, usando a correspondente decomposição do índice de Gini. São consideradas as seguintes parcelas do rendimento: rendimento do trabalho principal, rendimento de outros trabalhos, aposentadorias e pensões, doações, rendimento de aluguel e juros e outros rendimentos. Apenas os rendimentos do trabalho principal e as doações têm razões de concentração menores do que o índice de Gini do rendimento domiciliar per capita. Verificase que aposentadorias e pensões contribuem para aumentar a desigualdade da distribuição da renda no Brasil, especialmente nas regiões metropolitanas. Devido ao crescimento da participação dos idosos na população, se não houver mudanças no sistema de previdência, a contribuição das aposentadorias e pensões para reforçar a desigualdade será ainda maior no futuro.

\footnotetext{
${ }^{*}$ This paper was received in Feb. 2002 and approved in Oct. 2002. The study presented here was supported by $\mathrm{CNPq}$ and Fapesp. The author is grateful to Helga Hoffmann for her most valuable contribution in writing this paper.

${ }^{* *}$ Professor, Institute of Economics, Unicamp.
} 


\section{Introduction}

This paper analyzes how the components of household income contribute to the inequality of the distribution of per capita household income in Brazil, using data of 1999. The components analyzed are: income from the main occupation, income from other occupations, retirement pensions and other pensions, rents, and other incomes (interest, dividends, etc.).

A striking result is that retirement pensions contribute considerably to the inequality of income distribution in the majority of the metropolitan regions of the country.

Several authors noted already that expenditures with retirement pensions and other pensions are not well focused if they are to be considered as social expenditures with the aim of fighting poverty (Amsberg et al., 2000, Barros and Foguel, 2000). Other researches examined the relationship between pensions, age and poverty (Barros et al., 1999, 2000, Delgado and Cardoso Jr., 2000).

The next section presents the data; section 3 contains a summary of the methodology for decomposition of the Gini index; section 4 analyzes tables with the distribution of population, of family income, and of its components in 10 classes of per capita household income; section 5 presents the results of the decomposition of the Gini index for Brazil, in six Brazilian regions and in the metropolitan areas; and section 6 is a summary of the main conclusions.

\section{The Data}

The data used here are from the Brazilian National Sample Survey of Households of 1999, which will be referred to by the acronym Pnad (for its Brazilian title, Pesquisa Nacional por Amostra de Domicilios).

The Brazilian National Statistics Office, IBGE (for Instituto Brasileiro de Geografia e Estatística) informs that it "considers as monthly household income the sum of monthly incomes of those living in the same household, excluding those in pension (paid guests), domestic servants and family members of domestic servants". Per capita income was obtained by dividing the household income by the number of persons in the household (excluding those in pension, domestic servants and family members of servants). Only permanent private households that declared an income were considered, namely, a total of 91,574 households in the 
sample, corresponding to $41,861,683$ households in the population as a whole, or 155.6 million people in the category being examined.

One should bear in mind the limitations of the income data resulting from the Pnad questionnaire. Total declared income underestimates considerably the national income. The main reason for this is, probably, that families avoided declaring all their income, in particular those with the highest incomes. Another reason, however, is that the Pnad does not capture the value of production for self-consumption. The income of those producing agricultural goods is hard to measure precisely and a significant part of incomes derived from the ownership of capital is certainly not declared.

It should be noted that the category 'income from work' (rendimento do trabalho), for the Brazilian National Statistics Office, includes incomes obtained from any activity that an individual had (and declared), and is not limited to wages. 'Income from work' comprehends the income of self-employed and employers. We prefer thus to use here the expressions 'income from all occupations' (income from the main occupation and income from other occupations).

A final reminder on the data: Pnad does not collect data for the rural areas of the former North Region (states of Rondonia, Acre, Amazonas, Roraima, Pará and Amapá).

\section{Decomposition of the Gini Index}

Pyatt et al. (1980) have shown very clearly how the Gini index may be decomposed, when one wants to analyze incomes divided in their various components. ${ }^{1}$

Let $y_{i}$ be the income of the $i^{t h}$ person. This paper deals with the per capita household income, assuming that this income is the sum of $k$ parts

$$
y_{i}=\sum_{h=1}^{k} y_{h i}
$$

Suppose those incomes $y_{i}$ are ordered so that $y_{1} \leq y_{2} \leq \ldots \leq y_{n}$, where $n$ is the size of the population. Thus, $i$ is the rank of income $y_{i}$.

It can be shown that the Gini index $(G)$ of the distribution of $y_{i}$ is

$$
G=\frac{2}{n \mu} \operatorname{cov}\left(y_{i}, i\right)
$$

\footnotetext{
${ }^{1}$ See also Shorrocks $(1982,1983)$. In Brazil this methodology was already used by Neder (2001) and Mariano and Lima (1998).
} 
where $\mu$ is the average of $y_{i}$.

Pyatt et al. (1980) define the concentration ratio of the component $y_{h i}$ as

$$
C_{h}=\frac{2}{n \mu_{h}} \operatorname{cov}\left(y_{h i}, i\right)
$$

where $\mu_{h}$ is the average of $y_{h i}$. For non-negative incomes the Gini index varies from zero to $(n-1) / n$ and the concentration ratio varies from $-(n-1) / n$ to $(n-1) / n$ The participation of the $h^{t h}$ component in the total income is

$$
\phi_{h}=\frac{\mu_{h}}{\mu}
$$

It can be deduced that

$$
G=\sum_{h=1}^{k} \phi_{h} C_{h}
$$

Let us indicate by $i_{h}$ the ranks associated to the values of $y_{h i}$ if they were in increasing order. The values of $i_{h}$, the same as $i$, vary from 1 to $n$. Note, however, that for a given $y_{h i}$, the respective value of $i$ (the rank of the corresponding $y_{i}$ ) will not coincide, in general, with $i_{h}$ (the rank of this $y_{h i}$ in the ordering of the values of that component). Analogous to (2), the Gini index of $y_{h i}$ is

$$
G_{h}=\frac{2}{n \mu_{h}} \operatorname{cov}\left(y_{h i}, i_{h}\right)
$$

From (3) and (6), we obtain

$$
R_{h}=\frac{C_{h}}{G_{h}}=\frac{\operatorname{cov}\left(y_{h i}, i\right)}{\operatorname{cov}\left(y_{h i}, i_{h}\right)}
$$

Pyatt et al. (1980) call $R_{h}$ 'rank correlation ratio', stressing that it is not a rank correlation coefficient. It can be shown that

$$
-1 \leq R_{h} \leq 1
$$

Hence $-G_{h} \leq C_{h} \leq G_{h}$

From (5) and (7), it follows that

$$
G=\sum_{h=1}^{k} \phi_{h} R_{h} G_{h}
$$


This expression shows how the Gini index of $y_{i}$ is associated with the Gini indices of each component.

Note, in expression (5), that if all the concentration rations $C_{h}$ had the same value, this would be also the value of $G$. Thus, it is reasonable to admit that a component $y_{h i}$ contributes to increase inequality (measured by the Gini index) when $C_{h}>G$. When $C_{h}<G$, the component $y_{h i}$ will be contributing to reduce inequality compared to that hypothetical situation in which all $C_{h}$ are the same.

Obviously one item of the sum in the right-hand member of expression (8) will be negative only if the respective $R_{h}$ is negative. This, on its turn, can only happen if $\operatorname{cov}\left(y_{h i}, i\right)<0$, as shown in expression (7).

All calculations in this paper were made considering the weight or expansion factor for each household in the Pnad sample as supplied by IBGE.

\section{Distribution in 10 Income Classes}

In this section we analyze tables classifying households in 10 classes of per capita household income. Table 1 shows the distribution of permanent private households and of the corresponding people in these 10 classes. The first class includes those households that declared their income to be zero. It should be recalled that households where any person did not declare his/her income were excluded from this analysis.

Table 1 also presents the per capita income in each class and its share in the total income declared.

Table 2 presents the distribution, in these 10 classes, of four components of household income: income from the main occupation of the occupied persons in the household, income from other occupations, retirement pensions and other pensions, and other incomes. Here 'retirement' includes retirement caused by disability.

In table 3 the income from retirement pensions and other pensions is disaggregated in three parts: 'official' retirement pensions (paid by the federal government or by federal, state or municipal social security institutes), other 'official' pensions (widows etc.), and other retirement pensions and other pensions. The same table 3 presents the three components of 'other incomes' (the sum of which was in table 2): donations, rents, and a component that includes interest, dividends and other incomes. 
Those households with per capita income up to $\mathrm{R} \$ 150$ represent $50.5 \%$ of the total number of households and $56.8 \%$ of all people, and absorb $16.5 \%$ of the total income. At the other end, the households with per capita incomes above $\mathrm{R} \$ 500$ constitute $14.6 \%$ of the total, comprising $11.3 \%$ of the people, and receive $49.7 \%$ of the total income. This group of the relatively rich absorbs $48.5 \%$ of the total income derived from an occupation, $51.6 \%$ of all the income that comes from retirement pensions and other pensions, and $53.2 \%$ of the income that results from 'official' retirement pensions. It is striking that the income derived from pensions is more concentrated among the relatively rich households than the income obtained from all sources altogether. Such concentration is even heavier for 'official' retirement pensions.

Table 1

Distribution of households and persons in 10 classes of per capita household income

(Brazil, 1999)

\begin{tabular}{|c|c|c|c|c|c|c|}
\hline \multirow{2}{*}{$\begin{array}{l}\text { Class of } \\
\text { per capita } \\
\text { household } \\
\text { income } \\
(\mathrm{R} \$)\end{array}$} & \multicolumn{2}{|c|}{ Households } & \multicolumn{2}{|c|}{ Persons } & \multirow{2}{*}{$\begin{array}{l}\text { Average per capita } \\
\text { income }(\mathrm{R} \$)\end{array}$} & \multirow{2}{*}{$\begin{array}{l}\% \text { of total } \\
\text { income }\end{array}$} \\
\hline & No. $\left(10^{3}\right)$ & $\%$ & No. $\left(10^{3}\right)$ & $\%$ & & \\
\hline 0 & 609.6 & 1.5 & 1,937 & 1.2 & 0 & 0 \\
\hline Over 0 to 50 & $5,500.3$ & 13.1 & 28,009 & 18.0 & 32.2 & 2.3 \\
\hline Over 50 to 100 & $7,983.9$ & 19.1 & 34,057 & 21.9 & 75.5 & 6.5 \\
\hline Over 100 to 150 & $7,041.1$ & 16.8 & 24,387 & 15.7 & 126.5 & 7.8 \\
\hline Over 150 to 200 & $4,368.2$ & 10.4 & 15,822 & 10.2 & 176.4 & 7.0 \\
\hline Over 200 to 300 & $5,421.4$ & 13.0 & 18,270 & 11.7 & 248.4 & 11.4 \\
\hline Over 300 to 500 & $4,831.8$ & 11.5 & 15,582 & 10.0 & 389.4 & 15.3 \\
\hline Over 500 to 1000 & $3,722.5$ & 8.9 & 11,272 & 7.2 & 702.1 & 20.0 \\
\hline Over 1000 to 2000 & $1,659.3$ & 4.0 & 4,597 & 3.0 & $1,393.4$ & 16.1 \\
\hline Over 2000 & 723.6 & 1.7 & 1,640 & 1.1 & $3,283.7$ & 13.6 \\
\hline Total & $41,861.7$ & 100.0 & 155,575 & 100.0 & 254.9 & 100.0 \\
\hline
\end{tabular}

One way of assessing the degree of concentration of the various types of income in favor of the relatively rich is to calculate the ratio between the participation of the relatively rich (per capita household income above $\mathrm{R} \$ 500$ ) in the total of that type of income and the participation of the relatively poor (per capita household income up to $\mathrm{R} \$ 150$ ). This ratio is 3.0 for the income from all sources (pensions included), 2.8 for the income derived from the main occupation, 8.0 for the income from other occupations, 2.9 for the income from all occupations, 3.3 for 'official' retirement pensions, 2.1 for 'official' pensions that do not include the retirement pension, 3.4 for other retirement pensions and other pensions, 15.7 for rents, 1.0 for donations, 4.7 for interest and other incomes. 
Table 2

Distribution of components of household income in classes of per capita household income (Brazil, 1999)

\begin{tabular}{lccccc}
\hline $\begin{array}{c}\text { Class of per capita } \\
\text { household income }(\mathrm{R} \$)\end{array}$ & $\begin{array}{c}\text { Main } \\
\text { occupation }\end{array}$ & $\begin{array}{c}\text { Other } \\
\text { occupations }\end{array}$ & $\begin{array}{c}\text { All } \\
\text { occupations }\end{array}$ & $\begin{array}{c}\text { Retirement } \\
\text { and other } \\
\text { pensions }\end{array}$ & $\begin{array}{c}\text { Other } \\
\text { incomes* }\end{array}$ \\
\hline O & 0 & 0 & 0 & 0 & 0 \\
Over 0 to 50 & 2.4 & 2.0 & 2.4 & 1.8 & 2.7 \\
Over 50 to 100 & 6.8 & 3.4 & 6.6 & 6.1 & 4.8 \\
Over 100 to 150 & 7.8 & 3.5 & 7.6 & 9.2 & 4.5 \\
Over 150 to 200 & 7.6 & 3.2 & 7.4 & 6.0 & 4.3 \\
Over 200 to 300 & 12.0 & 6.1 & 11.7 & 10.9 & 7.7 \\
Over 300 to 500 & 15.9 & 10.7 & 15.7 & 14.5 & 11.1 \\
Over 500 to 1000 & 19.8 & 21.2 & 19.9 & 20.6 & 18.9 \\
Over 1000 to 2000 & 15.6 & 24.8 & 15.9 & 16.6 & 18.7 \\
Over 2000 & 12.3 & 25.0 & 12.8 & 14.4 & 27.3 \\
\hline Total & 100.0 & 100.0 & 100.0 & 100.0 & 100.0 \\
\hline * Including donation
\end{tabular}

* Including donations, rents, interest, dividends etc.

Table 3

Distribution of components of pensions and other incomes in classes of per capita household income (Brazil, 1999)

\begin{tabular}{|c|c|c|c|c|c|c|}
\hline $\begin{array}{c}\text { Class of per } \\
\text { capita household } \\
\text { income }(\mathrm{R} \$)\end{array}$ & $\begin{array}{l}\text { 'Official' } \\
\text { retirement } \\
\text { pensions }\end{array}$ & $\begin{array}{c}\text { Other } \\
\text { 'official' } \\
\text { pensions }\end{array}$ & $\begin{array}{l}\text { Other } \\
\text { retirement and } \\
\text { other pensions }\end{array}$ & Donations & Rents & $\begin{array}{l}\text { Interest, } \\
\text { dividends } \\
\text { etc. }\end{array}$ \\
\hline 0 & 0 & 0 & 0 & 0 & 0 & 0 \\
\hline Over 0 to 50 & 1.6 & 2.5 & 2.2 & 9.9 & 0.3 & 2.8 \\
\hline Over 50 to 100 & 5.8 & 7.4 & 6.1 & 12.9 & 1.8 & 6.0 \\
\hline Over 100 to 150 & 8.9 & 11.0 & 7.7 & 9.0 & 2.6 & 6.0 \\
\hline Over 150 to 200 & 5.7 & 6.6 & 6.8 & 8.2 & 3.2 & 3.7 \\
\hline Over 200 to 300 & 10.5 & 13.0 & 9.8 & 11.1 & 7.3 & 6.0 \\
\hline Over 300 to 500 & 14.4 & 15.4 & 13.5 & 15.7 & 11.2 & 7.0 \\
\hline Over 500 to 1,000 & 20.6 & 20.0 & 22.9 & 18.8 & 20.7 & 14.0 \\
\hline Over 1,000 to 2,000 & 17.5 & 13.6 & 15.7 & 9.0 & 22.8 & 16.5 \\
\hline Over 2,000 & 15.2 & 10.6 & 15.3 & 5.4 & 30.2 & 38.2 \\
\hline Total & 100.0 & 100.0 & 100.0 & 100.0 & 100.0 & 100.0 \\
\hline
\end{tabular}

Instead of showing the shares in the columns, as in tables 1 to 3 , table 4 presents the percentages in the lines, that is, it shows the share of each component in the total income of the given income class. The income of the main occupation always prevails ( $75.5 \%$ in the total of all classes), but it tends to diminish with the rise of the per capita household income. On the other hand, the participation of the income from other occupations tends to increase with per capita income, especially in the three highest income classes. 
Table 4

Share of the components of household income according to classes of per capita household income (Brazil, 1999)

\begin{tabular}{|c|c|c|c|c|c|c|c|}
\hline \multirow{2}{*}{$\begin{array}{c}\text { Class of } \\
\text { per capita } \\
\text { household } \\
\text { income }(\mathrm{R} \$)\end{array}$} & \multicolumn{6}{|c|}{ Share (\%) of income } & \multirow[b]{2}{*}{ * Rents } \\
\hline & $\begin{array}{c}\text { Main } \\
\text { occupation }\end{array}$ & $\begin{array}{c}\text { Other } \\
\text { occupation }\end{array}$ & $\begin{array}{c}\text { Retirement } \\
\text { and other } \\
\text { pensions }\end{array}$ & $\begin{array}{c}\text { 'Official' } \\
\text { retirement } \\
\text { pensions }\end{array}$ & $\begin{array}{c}\text { Other } \\
\text { 'official' } \\
\text { pensions }\end{array}$ & $\begin{array}{c}\text { Other } \\
\text { incomes* }\end{array}$ & \\
\hline Over 0 to 50 & 79.1 & 2.7 & 13.9 & 9.0 & 3.6 & 4.4 & 0.3 \\
\hline Over 50 to 100 & 78.8 & 1.5 & 16.9 & 11.9 & 3.8 & 2.8 & 0.6 \\
\hline Over 100 to 150 & 75.5 & 1.3 & 21.0 & 15.1 & 4.7 & 2.2 & 0.7 \\
\hline Over 150 to 200 & 81.3 & 1.4 & 15.1 & 10.7 & 3.1 & 2.3 & 1.0 \\
\hline Over 200 to 300 & 79.0 & 1.6 & 17.0 & 12.1 & 3.8 & 2.5 & 1.4 \\
\hline Over 300 to 500 & 78.4 & 2.1 & 16.9 & 12.4 & 3.4 & 2.7 & 1.6 \\
\hline Over 500 to 1,000 & 74.9 & 3.2 & 18.4 & 13.6 & 3.4 & 3.5 & 2.3 \\
\hline Over 1,000 to 2,000 & 72.8 & 4.6 & 18.3 & 14.3 & 2.8 & 4.3 & 3.1 \\
\hline Over 2,000 & 68.2 & 5.5 & 18.8 & 14.8 & 2.6 & 7.4 & 4.8 \\
\hline Total & 75.5 & 3.0 & 17.8 & 13.2 & 3.3 & 3.7 & 2.2 \\
\hline
\end{tabular}

Note, in table 4, that the participation of retirement and other pensions is relatively high in the income class 'over 100 to 150', because into this class comes the value of the minimum wage ( $\mathrm{R} \$ 136$ in September 1999), which is a very common amount for retirement and other pensions. All the households that have only retirees, each receiving a minimum wage, appear in this income class.

Taken together, the income from all occupations, plus pensions, reaches $96.3 \%$ of the total income. All other incomes (including donations, rents, interest, and dividends) constitute only $3.7 \%$ of the total. To some extent such a small share is due to the fact that these incomes are particularly understated.

Tables 5 to 9 show the distribution, in the same classes, of the households, the persons, the total income and four of its components for the metropolitan areas of Brazil, the urban non-metropolitan areas, the rural non-metropolitan areas, the metropolitan areas of the Northeast region of Brazil, and the metropolitan area of São Paulo. Metropolitan areas include 47.2 million people, $30.4 \%$ of the population analyzed (155.6 million people).

Observe, in the metropolitan areas of Brazil (table 5), that households with per capita income above $\mathrm{R} \$ 500$ comprise $22.7 \%$ of the total number of households, shelter $17.9 \%$ of the people, take $59.9 \%$ of total income, $58.4 \%$ of the income of all occupations, $62.8 \%$ of the pensions and $64.5 \%$ of the 'official' retirement pensions. In this case the concentration of retirement incomes in favor of the relatively rich is very clear. 
Table 5

Distribution of households, persons and various components of income in 10 classes of per capita household income (metropolitan Brazil, 1999)

\begin{tabular}{|c|c|c|c|c|c|c|c|}
\hline $\begin{array}{c}\text { Class of } \\
\text { per capita } \\
\text { household } \\
\text { income } \\
(\mathrm{R} \$)\end{array}$ & $\begin{array}{c}\text { Households } \\
(\%)\end{array}$ & $\begin{array}{c}\text { Persons } \\
(\%)\end{array}$ & $\begin{array}{c}\text { Total } \\
\text { income } \\
(\%)\end{array}$ & $\begin{array}{c}\text { Income } \\
\text { from } \\
\text { main } \\
\text { occupation } \\
(\%)\end{array}$ & $\begin{array}{c}\text { Income } \\
\text { from } \\
\text { all } \\
\text { occupations } \\
(\%)\end{array}$ & $\begin{array}{c}\text { Pensions } \\
(\%)\end{array}$ & $\begin{array}{c}\text { 'Official' } \\
\text { retirement } \\
\text { pensions } \\
(\%)\end{array}$ \\
\hline$\overline{0}$ & 1.7 & 1.4 & 0 & 0 & 0 & 0 & 0 \\
\hline Over 0 to 50 & 6.4 & 9.0 & 0.9 & 0.9 & 0.9 & 0.8 & 0.5 \\
\hline Over 50 to 100 & 13.9 & 16.8 & 3.6 & 4.0 & 3.9 & 2.7 & 2.2 \\
\hline Over 100 to 150 & 14.8 & 15.5 & 5.5 & 5.9 & 5.7 & 5.0 & 4.2 \\
\hline Over 150 to 200 & 11.0 & 11.6 & 5.7 & 6.3 & 6.1 & 4.6 & 4.2 \\
\hline 200 to 300 & 15.0 & 14.5 & 10.0 & 10.5 & 10.3 & 9.8 & 9.7 \\
\hline Over 300 to 500 & 14.6 & 13.2 & 14.4 & 14.9 & 14.7 & 14.4 & 14.6 \\
\hline Over 500 to 1,000 & 13.0 & 11.0 & 21.4 & 21.3 & 21.3 & 22.6 & 22.7 \\
\hline Over 1,000 to 2,000 & 6.4 & 4.9 & 19.2 & 18.8 & 19.0 & 19.8 & 20.5 \\
\hline Over 2,000 & 3.3 & 2.1 & 19.3 & 17.5 & 18.1 & 20.4 & 21.3 \\
\hline Total & 100.0 & 100.0 & 100.0 & 100.0 & 100.0 & 100.0 & 100.0 \\
\hline
\end{tabular}

The same concentration is present in the non-metropolitan urban areas (table 6 ). Households with per capita income above $\mathrm{R} \$ 500$ are $13.6 \%$ of the total, constitute $10.8 \%$ of the people, take $45.6 \%$ of the total income, $44.5 \%$ of the income of all occupations, $47.5 \%$ of the sum of pensions and $50.2 \%$ of 'official' retirement pensions.

Table 6

Distribution of households, persons and various components of income in 10 classes of per capita household income (urban non-metropolitan Brazil, 1999)

\begin{tabular}{|c|c|c|c|c|c|c|c|}
\hline $\begin{array}{c}\text { Class of } \\
\text { per capita } \\
\text { household } \\
\text { income } \\
(\mathrm{R} \$)\end{array}$ & $\begin{array}{l}\text { Households } \\
(\%)\end{array}$ & $\begin{array}{c}\text { Persons } \\
(\%)\end{array}$ & $\begin{array}{c}\text { Total } \\
\text { income } \\
(\%)\end{array}$ & $\begin{array}{c}\text { Income } \\
\text { from } \\
\text { main } \\
\text { occupation } \\
(\%)\end{array}$ & $\begin{array}{c}\text { Income } \\
\text { from } \\
\text { all } \\
\text { occupations } \\
(\%)\end{array}$ & $\begin{array}{c}\text { Pensions } \\
(\%)\end{array}$ & $\begin{array}{l}\text { 'Official' } \\
\text { retirement } \\
\text { pensions } \\
(\%)\end{array}$ \\
\hline$\overline{0}$ & 1.3 & 1.2 & 0 & 0 & 0 & 0 & 0 \\
\hline Over 0 to 50 & 10.9 & 14.9 & 2.0 & 2.1 & 2.0 & 1.8 & 1.6 \\
\hline Over 50 to 100 & 19.3 & 22.4 & 6.8 & 7.1 & 6.9 & 6.7 & 6.1 \\
\hline Over 100 to 150 & 17.7 & 16.4 & 8.3 & 8.3 & 8.1 & 10.4 & 9.8 \\
\hline Over 150 to 200 & 11.0 & 10.9 & 7.8 & 8.4 & 8.2 & 6.4 & 6.1 \\
\hline Over 200 to 300 & 13.8 & 12.7 & 12.7 & 13.3 & 13.1 & 11.7 & 10.9 \\
\hline Over 300 to 500 & 12.3 & 10.8 & 16.8 & 17.4 & 17.2 & 15.6 & 15.3 \\
\hline Over 500 to 1,000 & 8.7 & 7.2 & 20.5 & 20.3 & 20.4 & 20.7 & 20.8 \\
\hline Over 1,000 to 2,000 & 3.6 & 2.7 & 15.2 & 14.3 & 14.8 & 15.9 & 17.3 \\
\hline Over 2,000 & 1.3 & 0.8 & 9.9 & 8.8 & 9.3 & 10.9 & 12.2 \\
\hline Total & 100.0 & 100.0 & 100.0 & 100.0 & 100.0 & 100.0 & 100.0 \\
\hline
\end{tabular}


In the rural areas (table 7), the concentration of retirement pensions in favor of the rich is apparently not stronger than that for income taken as a whole. On the contrary, the participation of the richest households in the income from pensions is significantly lower than their participation in the income from all occupations. In these areas, households with per capita income above $\mathrm{R} \$ 500$ constitute $2.8 \%$ of the total, comprise $2.0 \%$ of the people, receive $20.1 \%$ of the total income, $21.0 \%$ of the income from all occupations and only $13.9 \%$ of the income coming from pensions.

Nevertheless, a higher concentration of pensions can be detected if a different aggregation of income classes is used. Households with per capita income above $\mathrm{R} \$ 100$ are $39.4 \%$ of the total, have $29.8 \%$ of all persons, take $68.9 \%$ of the total income, $68.3 \%$ of the income of all occupation, $70.6 \%$ of pensions and $71.1 \%$ of all 'official' retirement pensions. Note that in this aggregation of income classes the limit used to define the 'relatively rich' is lower than one minimum wage ( $\mathrm{R} \$ 136$ in 1999). The apparent stronger concentration of pensions than of all income in all likelihood is due to the fact that incomes from farming are understated and that the value of production for self-consumption is omitted. ${ }^{2}$

Table 7

Distribution of households, persons and various components of income in 10 classes of per capita household income (rural non-metropolitan Brazil, 1999)

\begin{tabular}{|c|c|c|c|c|c|c|c|}
\hline $\begin{array}{l}\text { Class of } \\
\text { per capita } \\
\text { household } \\
\text { income } \\
(\mathrm{R} \$)\end{array}$ & $\begin{array}{c}\text { Households } \\
(\%)\end{array}$ & $\begin{array}{c}\text { Persons } \\
(\%)\end{array}$ & $\begin{array}{c}\text { Total } \\
\text { income } \\
(\%)\end{array}$ & $\begin{array}{c}\text { Income } \\
\text { from } \\
\text { main } \\
\text { occupation } \\
(\%)\end{array}$ & $\begin{array}{c}\text { Income } \\
\text { from } \\
\text { all } \\
\text { occupations } \\
(\%)\end{array}$ & $\begin{array}{c}\text { Pensions } \\
(\%)\end{array}$ & $\begin{array}{c}\text { 'Official' } \\
\text { retirement } \\
\text { pensions } \\
(\%)\end{array}$ \\
\hline$(-0,7)$ & 1.4 & 1.2 & 0 & 0 & 0 & 0 & 0 \\
\hline Over 0 to 50 & 31.5 & 40.4 & 11.4 & 12.2 & 12.3 & 7.1 & 6.5 \\
\hline Over 50 to 100 & 27.7 & 28.6 & 19.8 & 19.6 & 19.4 & 22.3 & 22.4 \\
\hline Over 100 to 150 & 18.0 & 14.0 & 16.6 & 15.0 & 14.8 & 25.5 & 26.6 \\
\hline Over 150 to 200 & 7.7 & 5.9 & 9.7 & 9.6 & 9.5 & 11.1 & 11.2 \\
\hline Over 200 to 300 & 6.9 & 4.9 & 11.5 & 11.5 & 11.5 & 11.8 & 11.4 \\
\hline Over 300 to 500 & 3.9 & 3.0 & 10.9 & 11.4 & 11.5 & 8.2 & 8.0 \\
\hline Over 500 to 1,000 & 2.0 & 1.4 & 9.0 & 8.8 & 8.9 & 9.0 & 8.9 \\
\hline Over 1000 to 2,000 & 0.7 & 0.4 & 6.0 & 6.3 & 6.6 & 3.3 & 3.1 \\
\hline Over 2,000 & 0.2 & 0.1 & 5.1 & 5.6 & 5.5 & 1.6 & 2.0 \\
\hline Total & 100.0 & 100.0 & 100.0 & 100.0 & 100.0 & 100.0 & 100.0 \\
\hline
\end{tabular}

\footnotetext{
${ }^{2}$ See Delgado and Cardoso Jr. (2000) for an analysis of the beneficial impact of rural social security on poverty and small farmers.
} 
The evidence presented up to now reveals a stronger concentration of pensions in favor of the relatively rich in the urban areas. We will examine in particular the metropolitan areas of the Northeast (table 8) and the metropolitan area of São Paulo (table 9).

In the metropolitan areas of the Northeast that concentration is striking. Households with per capita income above $\mathrm{R} \$ 500$ are $13.1 \%$ of the total, shelter $9.9 \%$ of the people, and receive $51.9 \%$ of the total income, $50.2 \%$ of the income from all occupations, $56.9 \%$ of pensions, and 60.0 of 'official' retirement pensions.

Table 8

Distribution of households, persons and various components of income in 10 classes of per capita household income (metropolitan Northeast of Brazil, 1999)

\begin{tabular}{|c|c|c|c|c|c|c|c|}
\hline $\begin{array}{c}\text { Class of } \\
\text { per capita } \\
\text { household } \\
\text { income } \\
(\mathrm{R} \$)\end{array}$ & $\begin{array}{l}\text { Households } \\
(\%)\end{array}$ & $\begin{array}{c}\text { Persons } \\
(\%)\end{array}$ & $\begin{array}{c}\text { Total } \\
\text { income } \\
(\%)\end{array}$ & $\begin{array}{c}\text { Income } \\
\text { from } \\
\text { main } \\
\text { occupation } \\
(\%)\end{array}$ & $\begin{array}{c}\text { Income } \\
\text { from } \\
\text { all } \\
\text { occupations } \\
(\%)\end{array}$ & $\begin{array}{c}\text { Pensions } \\
(\%)\end{array}$ & $\begin{array}{c}\text { 'Official' } \\
\text { retirement } \\
\text { pensions } \\
(\%)\end{array}$ \\
\hline 0 & 1.8 & 1.4 & 0 & 0 & 0 & 0 & 0 \\
\hline Over 0 to 50 & 16.2 & 21.2 & 3.1 & 3.3 & 3.2 & 2.3 & 1.8 \\
\hline Over 50 to 100 & 24.3 & 27.3 & 8.8 & 9.8 & 9.4 & 6.9 & 6.0 \\
\hline Over 100 to 150 & 16.7 & 15.6 & 8.4 & 9.0 & 8.7 & 7.7 & 7.2 \\
\hline Over 150 to 200 & 9.5 & 8.9 & 6.7 & 7.4 & 7.2 & 5.2 & 4.7 \\
\hline Over 200 to 300 & 10.0 & 8.6 & 9.2 & 9.5 & 9.3 & 9.1 & 8.9 \\
\hline Over 300 to 500 & 8.4 & 7.2 & 12.0 & 12.2 & 12.0 & 11.8 & 11.4 \\
\hline Over 500 to 1,000 & 7.1 & 5.7 & 17.3 & 16.5 & 16.5 & 20.4 & 20.0 \\
\hline Over 1,000 to 2,000 & 4.2 & 3.0 & 18.3 & 17.5 & 18.0 & 18.9 & 19.2 \\
\hline Over 2,000 & 1.8 & 1.2 & 16.3 & 14.7 & 15.6 & 17.6 & 20.8 \\
\hline Total & 100.0 & 100.0 & 100.0 & 100.0 & 100.0 & 100.0 & 100.0 \\
\hline
\end{tabular}

Table 9 shows that in the metropolitan region of São Paulo the concentration of pensions we have been examining is not present. Households with per capita income above $\mathrm{R} \$ 500$ are $26.6 \%$ of the total, include $21.5 \%$ of the people, $61.9 \%$ of the total income, $61.6 \%$ of the income from all occupations, $57.0 \%$ of pensions and $57.5 \%$ of 'official' retirement pensions. 
Table 9

Distribution of households, persons and various components of income in 10 classes of per capita household income (metropolitan region of São Paulo, 1999)

\begin{tabular}{|c|c|c|c|c|c|c|c|}
\hline $\begin{array}{c}\text { Class of } \\
\text { per capita } \\
\text { household } \\
\text { income } \\
(\mathrm{R} \$)\end{array}$ & $\begin{array}{c}\text { Households } \\
(\%)\end{array}$ & $\begin{array}{c}\text { Persons } \\
(\%)\end{array}$ & $\begin{array}{c}\text { Total } \\
\text { income } \\
(\%)\end{array}$ & $\begin{array}{c}\text { Income } \\
\text { from } \\
\text { main } \\
\text { occupation } \\
(\%) \\
\end{array}$ & $\begin{array}{c}\text { Income } \\
\text { from } \\
\text { all } \\
\text { occupations } \\
(\%) \\
\end{array}$ & $\begin{array}{c}\text { Pensions } \\
(\%)\end{array}$ & $\begin{array}{c}\text { 'Official' } \\
\text { retirement } \\
\text { pensions } \\
(\%)\end{array}$ \\
\hline$\overline{0}$ & 2.3 & 2.0 & 0 & 0 & 0 & 0 & 0 \\
\hline Over 0 to 50 & 3.8 & 5.4 & 0.5 & 0.5 & 0.5 & 0.5 & 0.3 \\
\hline Over 50 to 100 & 10.5 & 13.1 & 2.6 & 2.7 & 2.6 & 2.3 & 1.9 \\
\hline Over 100 to 150 & 13.2 & 14.3 & 4.5 & 4.7 & 4.6 & 5.1 & 4.3 \\
\hline Over 150 to 200 & 10.7 & 11.7 & 5.2 & 5.4 & 5.3 & 5.3 & 5.0 \\
\hline Over 200 to 300 & 15.5 & 15.9 & 9.8 & 10.0 & 9.8 & 11.1 & 11.6 \\
\hline Over 300 to 500 & 17.3 & 16.2 & 15.6 & 15.8 & 15.6 & 18.6 & 19.5 \\
\hline Over 500 to 1,000 & 15.7 & 13.4 & 23.0 & 22.4 & 22.5 & 27.1 & 28.5 \\
\hline Over 1,000 to 2,000 & 7.2 & 5.7 & 19.7 & 20.2 & 20.3 & 16.5 & 17.7 \\
\hline Over 2,000 & 3.7 & 2.4 & 19.1 & 18.4 & 18.8 & 13.4 & 11.2 \\
\hline Total & 100.0 & 100.0 & 100.0 & 100.0 & 100.0 & 100.0 & 100.0 \\
\hline
\end{tabular}

In the next section, we apply the methodology for the decomposition of the Gini index according to the different components of household income, in order to reach a more synthetic analysis of the contribution of pensions to income inequality in Brazil.

\section{Results of the Decomposition of the Gini Index}

Table 10 shows the results of the decomposition of the Gini index of the per capita household income in Brazil, considering six components: income from the main occupation of those persons who are occupied, income from other occupations, pensions, donations, rents, and an item that includes interest, dividends and other incomes. Of these components, only income from the main occupation and donations have a concentration ratio lower than the global Gini index. Although the concentration ratio of donations is the lowest, it is still positive, indicating that the value of per capita donations received tends to increase with the rise of the per capita household income.

Excluding the case of the income from the main occupation, the Gini indices of the components of income are all extremely high because a large proportion of people are in households where that component is zero; this proportion is $9.3 \%$ for income from the main occupation, $92.9 \%$ for income from other occupations, $67.7 \%$ for pensions, 97.0 for donations, 96.2 for rents, $95.9 \%$ for interest and other incomes. And $1.2 \%$ of people are in households that have no income at all. 
Table 10

Decomposition of the Gini index for the per capita household income

(Brazil, 1999)

\begin{tabular}{lccccc}
\hline \multicolumn{1}{c}{ Components of } & $\begin{array}{c}\text { Average value } \\
\text { income }\end{array}$ & $(\mathrm{R} \$)$ & $\begin{array}{c}\text { Gini index } \\
\left(G_{h}\right)\end{array}$ & $\begin{array}{c}\text { Share } \% \\
\left(\phi_{h}\right)\end{array}$ & $\begin{array}{c}\text { Concentration ratio } \\
\left(C_{h}\right)\end{array}$ \\
\hline Main occupation & 192.4 & 0.628 & 75.5 & 0.579 & $\phi_{h} C_{h}$ \\
Other occupations & 7.6 & 0.978 & 3.0 & 0.745 & 0.437 \\
Pensions & 45.4 & 0.876 & 17.8 & 0.603 & 0.107 \\
Donations & 1.8 & 0.990 & 0.7 & 0.354 & 0.002 \\
Rents & 5.6 & 0.986 & 2.2 & 0.803 & 0.018 \\
Interest etc. & 2.1 & 0.991 & 0.8 & 0.695 & 0.006 \\
\hline Total & 254.9 & 0.592 & 100.0 & 0.592 & 0.592 \\
\hline
\end{tabular}

Table 10 shows that, due to its large share in the total income (75.5\%), income from the main occupation is responsible for the highest part of the Gini index (almost $74 \%$ of the total).

Among the remaining components, pensions play an important role, as they are $17.8 \%$ of the total income and generate $18.1 \%$ of the Gini index.

The role of pensions is more striking in the metropolitan areas (table 11), where they represent $18.3 \%$ of the total income and are responsible for $19.3 \%$ of the Gini index.

Table 11

Decomposition of the Gini index for the per capita household income (metropolitan Brazil, 1999)

\begin{tabular}{lccccc}
\hline \multicolumn{1}{c}{$\begin{array}{c}\text { Components of } \\
\text { income }\end{array}$} & $\begin{array}{c}\text { Average value } \\
(\mathrm{R} \$)\end{array}$ & $\begin{array}{c}\text { Gini index } \\
\left(G_{h}\right)\end{array}$ & $\begin{array}{c}\text { Share } \% \\
\left(\phi_{h}\right)\end{array}$ & $\begin{array}{c}\text { Concentration ratio } \\
\left(C_{h}\right)\end{array}$ & $\phi_{h} C_{h}$ \\
\hline Main occupation & 272.4 & 0.613 & 75.6 & 0.560 & 0.423 \\
Other occupations & 8.3 & 0.986 & 2.3 & 0.815 & 0.019 \\
Pensions & 65.8 & 0.875 & 18.3 & 0.613 & 0.112 \\
Donations & 2.4 & 0.992 & 0.7 & 0.445 & 0.003 \\
Rents & 7.7 & 0.985 & 2.1 & 0.762 & 0.016 \\
Interest etc. & 3.8 & 0.993 & 1.1 & 0.790 & 0.008 \\
\hline Total & 360.5 & 0.581 & 100.0 & 0.581 & 0.581 \\
\hline
\end{tabular}

In the urban non-metropolitan areas (table 12) the impact of pensions on the Gini index is 'neutral': those incomes represent $17.5 \%$ of the total income and originate $17.5 \%$ of the Gini index. This happens because the concentration ratio of pensions (0.562) is practically the same as the Gini index (0.560).

In the rural non-metropolitan areas (table 13) the concentration ratio of pensions (0.542) is somewhat higher that the Gini index of the aggregate (0.538), making the contribution of this item to the Gini index (17.5\%) slightly higher than its share in the aggregate income (17.4\%). 
Table 12

Decomposition of the Gini index for the per capita household income (urban non-metropolitan Brazil, 1999)

\begin{tabular}{|c|c|c|c|c|c|}
\hline $\begin{array}{l}\text { Components of } \\
\text { income }\end{array}$ & $\begin{array}{c}\text { Average value } \\
(\mathrm{R} \$)\end{array}$ & $\begin{array}{c}\text { Gini index } \\
\left(G_{h}\right)\end{array}$ & $\begin{array}{c}\text { Share \% } \\
\left(\phi_{h}\right)\end{array}$ & $\begin{array}{c}\text { Concentration ratio } \\
\left(C_{h}\right)\end{array}$ & $\phi_{h} C_{h}$ \\
\hline Main occupation & 187.5 & 0.598 & 75.4 & 0.545 & 0.411 \\
\hline Other occupations & 8.3 & 0.976 & 3.3 & 0.774 & 0.026 \\
\hline Pensions & 43.5 & 0.868 & 17.5 & 0.562 & 0.098 \\
\hline Donations & 1.8 & 0.986 & 0.7 & 0.242 & 0.002 \\
\hline Rents & 5.9 & 0.983 & 2.4 & 0.796 & 0.019 \\
\hline Interest etc. & 1.5 & 0.989 & 0.6 & 0.610 & 0.004 \\
\hline Total & 248.5 & 0.560 & 100.0 & 0.560 & 0.560 \\
\hline
\end{tabular}

Table 13

Decomposition of the Gini index for the per capita household income (rural non-metropolitan Brazil, 1999)

\begin{tabular}{lccccc}
\hline \multicolumn{1}{c}{$\begin{array}{c}\text { Components of } \\
\text { income }\end{array}$} & $\begin{array}{c}\text { Average value } \\
(\mathrm{R} \$)\end{array}$ & $\begin{array}{c}\text { Gini index } \\
\left(G_{h}\right)\end{array}$ & $\begin{array}{c}\text { Share } \% \\
\left(\phi_{h}\right)\end{array}$ & $\begin{array}{c}\text { Concentration ratio } \\
\left(C_{h}\right)\end{array}$ & $\phi_{h} C_{h}$ \\
\hline Main occupation & 79.3 & 0.595 & 75.4 & 0.535 & 0.403 \\
Other occupations & 4.5 & 0.952 & 4.3 & 0.543 & 0.023 \\
Pensions & 18.3 & 0.845 & 17.4 & 0.542 & 0.094 \\
Donations & 0.7 & 0.987 & 0.7 & 0.171 & 0.001 \\
Rents & 1.4 & 0.993 & 1.4 & 0.851 & 0.012 \\
Interest etc. & 1.0 & 0.986 & 1.0 & 0.507 & 0.005 \\
\hline Total & 105.3 & 0.538 & 100.0 & 0.538 & 0.538 \\
\hline
\end{tabular}

Tables 14a and 14b show summary results of the decomposition of the Gini index for the per capita household income for six Brazilian regions.

The portion of the Gini index associated to pensions is particularly large in the Northeast and in the grouping MG+ES+RJ (the three states - Minas Gerais, Espirito Santo and Rio de Janeiro), as in these regions one observes a high value of the concentration ratio $\left(C_{h}\right)$ as well as a high share of these incomes in the total income $\left(\phi_{h}\right)$.

It is interesting to compare the structure of the Gini index in the different regions and verify whether the differences in inequality in the total income are related to specific components of that income. Comparing the Southern region with the state of São Paulo we can see that the lower inequality measure in the latter is, to a large extent, due to the lower value of the portion related to pensions. 
Table 14a

Decomposition of the Gini index of the per capita household income in regions of Brazil, 1999: participation of the component in the total income $\left(\phi_{h}\right)$, concentration ratio $\left(C_{h}\right)$ and share of the component in the general Gini index $\left(\phi_{h} C_{h}\right)$

\begin{tabular}{|c|c|c|c|c|c|c|c|c|c|}
\hline \multirow[t]{2}{*}{ Components of income } & \multicolumn{3}{|c|}{ North } & \multicolumn{3}{|c|}{ Northeast } & \multicolumn{3}{|c|}{$\mathrm{MG}+\mathrm{ES}+\mathrm{RJ}$} \\
\hline & $\phi_{h}$ & $C_{h}$ & $\phi_{h} C_{h}$ & $\phi_{h}$ & $C_{h}$ & $\phi_{h} C_{h}$ & $\phi_{h}$ & $C_{h}$ & $\phi_{h} C_{h}$ \\
\hline Main occupation & 81.9 & 0.559 & 0.458 & 70.2 & 0.589 & 0.413 & 71.8 & 0.537 & 0.385 \\
\hline Other occupations & 3.3 & 0.792 & 0.026 & 5.0 & 0.705 & 0.035 & 2.8 & 0.802 & 0.023 \\
\hline Pensions & 12.2 & 0.541 & 0.066 & 21.4 & 0.630 & 0.135 & 22.4 & 0.628 & 0.140 \\
\hline Donations & 0.9 & 0.338 & 0.003 & 1.3 & 0.335 & 0.004 & 0.6 & 0.406 & 0.002 \\
\hline Rents & 1.3 & 0.735 & 0.010 & 1.4 & 0.856 & 0.012 & 1.8 & 0.770 & 0.014 \\
\hline Interest etc. & 0.4 & 0.758 & 0.003 & 0.7 & 0.524 & 0.004 & 0.6 & 0.577 & 0.004 \\
\hline Total & 100.0 & 0.566 & 0.566 & 100.0 & 0.604 & 0.604 & 100.0 & 0.568 & 0.568 \\
\hline
\end{tabular}

Comparing the Northeast and the South, it is easy to observe that almost all the difference in the Gini index of the two regions is associated to the portion regarding pensions.

Table 14b

Decomposition of the Gini index of the per capita household income in regions of Brazil, 1999: participation of the component in the total income $\left(\phi_{h}\right)$, concentration ratio $\left(C_{h}\right)$ and share of the component in the general Gini index $\left(\phi_{h} C_{h}\right)$

\begin{tabular}{|c|c|c|c|c|c|c|c|c|c|}
\hline \multirow[t]{2}{*}{ Components of income } & \multicolumn{3}{|c|}{ São Paulo } & \multicolumn{3}{|c|}{ South } & \multicolumn{3}{|c|}{ Center-West } \\
\hline & $\phi_{h}$ & $C_{h}$ & $\phi_{h} C_{h}$ & $\phi_{h}$ & $C_{h}$ & $\phi_{h} C_{h}$ & $\phi_{h}$ & $C_{h}$ & $\phi_{h} C_{h}$ \\
\hline Main occupation & 79.0 & 0.525 & 0.415 & 75.6 & 0.539 & 0.407 & 79.5 & 0.566 & 0.450 \\
\hline Other occupations & 1.8 & 0.791 & 0.014 & 3.5 & 0.793 & 0.027 & 2.9 & 0.777 & 0.022 \\
\hline Pensions & 15.0 & 0.524 & 0.078 & 16.8 & 0.568 & 0.096 & 13.9 & 0.661 & 0.092 \\
\hline Donations & 0.5 & 0.399 & 0.002 & 0.6 & 0.426 & 0.003 & 0.6 & 0.335 & 0.002 \\
\hline Rents & 2.7 & 0.758 & 0.020 & 2.5 & 0.791 & 0.020 & 2.4 & 0.740 & 0.018 \\
\hline Interest etc. & 1.0 & 0.789 & 0.008 & 1.0 & 0.683 & 0.007 & 0.7 & 0.676 & 0.004 \\
\hline Total & 100.0 & 0.538 & 0.538 & 100.0 & 0.560 & 0.560 & 100.0 & 0.589 & 0.589 \\
\hline
\end{tabular}

Tables 15a, 15b and 15c summarize the results of the decomposition of the Gini index in nine Brazilian metropolitan regions.

Regarding the portion of the Gini index associated to pensions, our attention is drawn to the higher values in Rio de Janeiro, Fortaleza and Recife. The share of pensions in the total income reaches $25.5 \%$ in Rio de Janeiro, $23.1 \%$ in the metropolitan region of Recife and is nearly $20 \%$ in Fortaleza, Salvador, Belo Horizonte and Porto Alegre, $18.6 \%$ in Brasilia, $14.3 \%$ in Curitiba and $13.1 \%$ in São Paulo.

Remarkable differences are exposed in the comparison between the largest metropolitan regions, São Paulo and Rio de Janeiro, which have almost the same Gini index. The portion $\phi_{h} C_{h}$ for pensions in Rio de Janeiro is far higher than the corresponding value for São Paulo. On the other hand, the portion for income 
from the main occupation is higher in São Paulo than the corresponding value in Rio de Janeiro. Also the portions corresponding to rents, as well as to dividends, interest and other incomes are higher in S Paulo. There are also differences in the concentration ratios. However, the main difference between Rio and São Paulo lies in the composition of income: while in Rio the share of income from the main occupation and the share of pensions in the total income are respectively $70.4 \%$ and $25.5 \%$, the corresponding shares in São Paulo are 80.6\% and 13.1\%.

Table $15 \mathrm{a}$

Decomposition of the Gini index of the per capita household income in metropolitan areas of Brazil, 1999: participation of the component in the total income $\left(\phi_{h}\right)$, concentration ratio $\left(C_{h}\right)$ and share of the component in the general Gini index $\left(\phi_{h} C_{h}\right)$

\begin{tabular}{|c|c|c|c|c|c|c|c|c|c|}
\hline \multirow[t]{2}{*}{ Components of income } & \multicolumn{3}{|c|}{ Fortaleza } & \multicolumn{3}{|c|}{ Recife } & \multicolumn{3}{|c|}{ Salvador } \\
\hline & $\phi_{h}$ & $C_{h}$ & $\phi_{h} C_{h}$ & $\phi_{h}$ & $C_{h}$ & $\phi_{h} C_{h}$ & $\phi_{h}$ & $C_{h}$ & $\phi_{h} C_{h}$ \\
\hline Main occupation & 72.1 & 0.579 & 0.417 & 69.7 & 0.601 & 0.419 & 72.6 & 0.600 & 0.436 \\
\hline Other occupations & 3.3 & 0.857 & 0.028 & 3.7 & 0.837 & 0.031 & 4.1 & 0.834 & 0.034 \\
\hline Pensions & 20.5 & 0.702 & 0.144 & 23.1 & 0.655 & 0.151 & 19.3 & 0.650 & 0.125 \\
\hline Donations & 1.6 & 0.396 & 0.006 & 1.2 & 0.349 & 0.004 & 1.2 & 0.552 & 0.007 \\
\hline Rents & 1.4 & 0.828 & 0.012 & 1.7 & 0.764 & 0.013 & 2.3 & 0.793 & 0.018 \\
\hline Interest etc. & 1.1 & 0.809 & 0.009 & 0.6 & 0.559 & 0.003 & 0.6 & 0.776 & 0.005 \\
\hline Total & 100.0 & 0.616 & 0.616 & 100.0 & 0.622 & 0.622 & 100.0 & 0.624 & 0.624 \\
\hline
\end{tabular}

Table 15b

Decomposition of the Gini index of the per capita household income in metropolitan areas of Brazil, 1999: participation of the component in the total income $\left(\phi_{h}\right)$, concentration ratio $\left(C_{h}\right)$ and share of the component in the general Gini index $\left(\phi_{h} C_{h}\right)$

\begin{tabular}{|c|c|c|c|c|c|c|c|c|c|}
\hline \multirow[t]{2}{*}{ Components of income } & \multicolumn{3}{|c|}{ Belo Horizonte } & \multicolumn{3}{|c|}{ Rio de Janeiro } & \multicolumn{3}{|c|}{ São Paulo } \\
\hline & $\phi_{h}$ & $C_{h}$ & $\phi_{h} C_{h}$ & $\phi_{h}$ & $C_{h}$ & $\phi_{h} C_{h}$ & $\phi_{h}$ & $C_{h}$ & $\phi_{h} C_{h}$ \\
\hline Main occupation & 73.6 & 0.543 & 0.400 & 70.4 & 0.516 & 0.363 & 80.6 & 0.547 & 0.441 \\
\hline Other occupations & 2.8 & 0.842 & 0.024 & 1.9 & 0.842 & 0.016 & 1.8 & 0.795 & 0.014 \\
\hline Pensions & 19.5 & 0.641 & 0.125 & 25.5 & 0.625 & 0.160 & 13.1 & 0.509 & 0.067 \\
\hline Donations & 0.6 & 0.585 & 0.003 & 0.7 & 0.425 & 0.003 & 0.5 & 0.505 & 0.003 \\
\hline Rents & 2.5 & 0.743 & 0.018 & 1.1 & 0.766 & 0.009 & 2.5 & 0.716 & 0.018 \\
\hline Interest etc. & 1.1 & 0.783 & 0.008 & 0.4 & 0.769 & 0.003 & 1.5 & 0.831 & 0.012 \\
\hline Total & 100.0 & 0.578 & 0.578 & 100.0 & 0.553 & 0.553 & 100.0 & 0.555 & 0.555 \\
\hline
\end{tabular}


Table $15 \mathrm{c}$

Decomposition of the Gini index of the per capita household income in metropolitan areas of Brazil, 1999: participation of the component in the total income $\left(\phi_{h}\right)$, concentration ratio $\left(C_{h}\right)$ and share of the component in the general Gini index $\left(\phi_{h} C_{h}\right)$

\begin{tabular}{|c|c|c|c|c|c|c|c|c|c|}
\hline \multirow[t]{2}{*}{ Components of income } & \multicolumn{3}{|c|}{ Curitiba } & \multicolumn{3}{|c|}{ Porto Alegre } & \multicolumn{3}{|c|}{ Brasilia (DF) } \\
\hline & $\phi_{h}$ & $C_{h}$ & $\phi_{h} C_{h}$ & $\phi_{h}$ & $C_{h}$ & $\phi_{h} C_{h}$ & $\phi_{h}$ & $C_{h}$ & $\phi_{h} C_{h}$ \\
\hline Main occupation & 77.2 & 0.530 & 0.410 & 71.4 & 0.528 & 0.377 & 76.6 & 0.595 & 0.456 \\
\hline Other occupations & 3.0 & 0.834 & 0.025 & 3.2 & 0.801 & 0.025 & 2.2 & 0.836 & 0.018 \\
\hline Pensions & 14.3 & 0.632 & 0.091 & 20.6 & 0.641 & 0.132 & 18.6 & 0.739 & 0.138 \\
\hline Donations & 0.6 & 0.515 & 0.003 & 0.6 & 0.617 & 0.004 & 0.4 & 0.134 & 0.001 \\
\hline Rents & 3.5 & 0.839 & 0.030 & 2.7 & 0.867 & 0.023 & 1.6 & 0.621 & 0.010 \\
\hline Interest etc. & 1.3 & 0.809 & 0.010 & 1.5 & 0.759 & 0.011 & 0.6 & 0.234 & 0.001 \\
\hline Total & 100.0 & 0.569 & 0.569 & 100.0 & 0.573 & 0.573 & 100.0 & 0.624 & 0.624 \\
\hline
\end{tabular}

\section{Conclusions}

The decomposition of the household income in its various components allows us to examine how each of them contributes to the strong inequality observed in Brazil.

According to the 1999 Pnad data, $75.5 \%$ of the average household income in Brazil results from the main occupation and $78.5 \%$ come from all occupations taken together (including own-account work and of employers' work). Pensions represent the next important component (17.8\%) of the total income.

The income from the main occupation is always less concentrated in favor of the rich than the total income, when people are classified according to their per capita household income. But this difference is small in rural areas. Income from other occupations (that is, excluded the main occupation) is always more concentrated than the total income. Once more, the difference is small in rural areas.

Pensions are, in general, more concentrated than the total income. This concentration is present also in rural areas, although the distribution of pensions in rural areas is in general very different from the one observed in urban areas.

In the metropolitan areas, pensions (and especially 'official' pensions) contribute substantially to increase inequality in the distribution of the per capita household income. This phenomenon is more accentuated in the cases of Fortaleza, Recife and Rio de Janeiro. The metropolitan area of São Paulo is the exception here: pensions are less concentrated in favor of the relatively rich than the total income.

It is very often said and written that Brazil is a country with strong inequality and that such inequality should be reduced. It is relevant to recognize that pre- 
cisely one component of income very much subject to laws and regulations, such as 'official' retirement pensions, is contributing to worsen inequality.

\section{References}

Amsberg, J. v., Lanjouw, P., \& Nead, K. (2000). A focalização do gasto social sobre a pobreza no Brasil. In Henriques, R., editor, Desigualdade e Pobreza No Brasil. Ipea, Rio de Janeiro.

Barros, R., Firpo, S., Mendonça, R., \& Santos, D. (2000). Aposentadoria e pobreza no Brasil. In Encontro Nacional de Economia, 28. Anais... Campinas.

Barros, R. \& Foguel, M. N. (2000). A focalização dos gastos públicos sociais e erradicação da pobreza no Brasil. In Henriques, R., editor, Desigualdade e Pobreza No Brasil. Ipea, Rio de Janeiro.

Barros, R., Mendonça, R., \& Santos, D. (1999). Incidência e natureza da pobreza entre idosos no Brasil. In Camarano, A. A., editor, Muito Além Dos 60: Os Novos Idosos Brasileiros. Ipea, Rio de Janeiro.

Bourguignon, F., Ferreira, F. H. G., \& Leite, P. G. (2001). Prices, preferences or endowments? accounting for excess inequality in Brazil. In Delgado, G. \& Cardoso Jr., J. C. O., editors, Encontro Brasileiro de Econometria, 23. Anais, Salvador.

Delgado, G. \& Cardoso Jr., J. C. O. (2000). A Universalização de Direitos Sociais No Brasil: A Previdência Rural Nos Anos 90. Ipea, Brasília.

IBGE (2000). Pesquisa Nacional Por Amostra de Domicílios, volume 21. Brasil.

Mariano, J. L. \& Lima, R. C. (1998). A desigualdade da renda rural no nordeste: Análise da desagregação do coeficiente de Gini e da sensibilidade do índice de bem-estar de Sen. Análise Econômica, 16(29):103-18.

Neder, H. D. (2001). Os efeitos das atividades não-agrícolas na distribuição de renda no meio rural. In Congresso Brasileiro de Economia e Sociologia Rural, 39. Anais. Sober, Recife. CD-ROM.

Neri, M. (2001). Recursos existem, falta qualidade. Conjuntura Econômica, 55(11):78-9. Rio de Janeiro. 
Pyatt, G., Chen, C.-N., \& Fei, J. (1980). The distribution of income by factor components. The Quarterly Journal of Economics, 95(3):451-73.

Ramos, C. A. (2000). Impacto distributivo do gasto público: Uma análise a partir da PCV/1998. Rio de Janeiro, Ipea. Texto para Discussão, 732.

Shorrocks, A. F. (1982). Inequality decomposition by factor components. Econometrica, 50(1):193-211.

Shorrocks, A. F. (1983). The impact of income components on the distribution of family incomes. Quarterly Journal of Economics, 98(2):311-26. 